\title{
SPECIAL FEATURES OF THE DEVELOPMENT OF FUTURE PSYCHOLOGISTS' COMMUNICATIVE COMPETENCE FOR PROFESSIONAL ACTIVITY
}

УДК 159.944

DOI https://doi.org/10.32843/2663-

5208.2020 .16 .18

\section{Бучацька С.М.}

к.психол.н., доцент кафедри методики навчання іноземних мов

Вінницький державний педагогічний університет імені Михайла

Коцюбинського

\section{Зарічна О.В}

к.пед.н., доцент касредри методики навчання іноземних мов

Вінницький державний педагогічний університет імені Михайла

Коцюбинського

\section{Хуртенко О.В.}

к.психол.н., доцент кафедри теорії і методики фрізичного виховання Вінницький державний педагогічний університет імені Михайла Коцюбинського

\author{
У статті визначено теоретико-методоло- \\ гічні засади та психологічні умови розвитку \\ комунікативної готовності майбутніх пси- \\ хологів до просресійної діяльності. Сфрокусо- \\ вано увагу на соціальну перцепцію; вольові \\ якості; інтеракційні вміння; сприйняття й \\ адекватне розуміння знакових систем: вер- \\ бальної й невербальної, пара- та екстра- \\ лінгвістичної - у структурі комунікативних \\ здібностей, якими повинен володіти май- \\ бутній психолог. \\ Проаналізовано основні рівні сформовано- \\ сті комунікативної готовності, яка включає \\ комунікативну толерантність психолога \\ під час роботи з людьми (прийняття інди- \\ відуальності клієнтів, відсутність оцінних \\ висловлювань на їхню адресу, терпимість до \\ іхніх дискомфортних станів, згладжування \\ неприємних моментів у спілкуванні з неко- \\ мунікабельними клієнтами), а також здат- \\ ність адекватно використовувати й роз- \\ пізнавати сигнали невербального мовлення \\ в спілкуванні з клієнтом. До дослідження \\ залучені 54 студенти 4 курсу спеціаль- \\ ності «Психологія» Вінницького державного \\ педагогічного університету імені Михайла \\ Кочюбинського, з яких - 27 осіб включено в \\ експериментальну групу і 27 - у контрольну. \\ Представлена програма розвитку кому- \\ нікативної готовності, відповідно до якої \\ передбачено саморозвиток особистості й \\ удосконалення нею засобів організації комуні- \\ кативної взаємодії в прочесі соціально-психо- \\ логічного тренінгу. Стаття містить аналіз \\ результатів упровадження тренінгу в про- \\ цес навчання майбутніх психологів у вищій \\ школі, що вказують на його ефрективність, \\ а саме усвідомлення студентами власних \\ установок у комунікативній ссері, експлі- \\ кацію наявних і вироблення продуктивніших \\ моделей пізнання особистості партнерів по \\ спілкуванню, освоєння певного рівня особи- \\ стісної рефрлексії та розвиток рефрлексив- \\ ного ставлення до себе як до суб'єктів про- \\ фоесійного спілкування, вироблення вміння \\ диреренціювати й адекватно виражати \\ власні почуття, використовуючи при цьому \\ весь арсенал вербальних $і$ невербальних \\ засобів комунікації. \\ Ключові слова: психологічна готовність, \\ комунікативна готовність, профресійна
}

діяльність, психологи, комунікативна толерантність, вербальні та невербальні засоби комунікації.

The article deals with the theoretical and methodological principles and psychological conditions for the development of future psychologists' communicative competence for professional activity. The focus has been made on social perception; volitional qualities; interaction skills; perception and adequate understanding of sign systems: verbal and nonverbal, para- and extralinguistic in the structure of a future psychologist's communicative abilities.

The main levels of communicative readiness, which include communicative tolerance of the psychologist when working with people (acceptance of clients' individuality, lack of evaluative statements addressed to them, tolerance to their uncomfortable states, smoothing of unpleasant moments in communication with non-communicative clients), and ability to use and recognize nonverbal speech signals in communication with the client have been analyzed. The study involved 54 4th year students majoring in "Psychology" of Vinnytsia State Pedagogical University named after Mykhailo Kotsyubynskyi: 27 students of which were included in the experimental group and 27 - in the control one. The program of the development of communicative competence suggested the self-development of the personality and improvement of means of the organization of communicative interaction in the course of social and psychological training. The article contains an analysis of the results of the future psychologists' training in higher education, indicating its effectiveness, specifically students' awareness of their own attitudes in communication, explication of existing and more productive models of cognition of communication partners, mastering a certain level of personal reflection and development of reflexive attitude to oneself as subjects of professional communication, developing the ability to differentiate and adequately express one's feelings, using the whole arsenal of verbal and nonverbal means of communication.

Key words: psychological disposition, communicative competence, professional activity, psychologists, communicative tolerance, verbal and nonverbal means of communication.
Постановка проблеми. Суттєвою передумовою ефективної професійної діяльності психолога $є$ його готовність успішно виконувати свої обов'язки, правильно використовувати знання, досвід, особистісні якості, зберігати самоконтроль і перебудовувати свою діяльність у разі непередбачуваних обставин. Серед вимог, які висуваються до майбутніх фахівців, варто назвати професійну придат- ність особистості (сукупність індивідуальних особливостей людини, здібностей і характерних рис, необхідних для успішного професійного спілкування та діяльності, а також підготовленість до діяльності (знання, уміння й навички, здобуті в процесі професійної підготовки)).

Отже, обґрунтованим $є$ інтерес до діяльності психологів як на етапі спеціальної підготовки, 
так і в період практичного застосування отриманих знань. Вагомого значення при цьому набуває формування психологічної готовності майбутніх психологів до професійної діяльності. Однак аналіз практики освітнього процесу свідчить про недостатній рівень зазначеної готовності, що проявляється, зокрема, у невмінні керувати своїм емоційним станом, у недостатньому рівні толерантності до думки, відмінної від власної, у нездатності вести діалог у рамках конструктивної суперечки тощо. Це, у свою чергу, актуалізує проблему визначення психологічних чинників та умов формування готовності майбутніх психологів до професійної взаємодії й комунікативної готовності зокрема.

Аналіз останніх досліджень і публікацій. У психологічній літературі $€$ дослідження, присвячені різним аспекти проблеми професійної підготовки психологів. Зокрема, розглянуті стандарти й вимоги до особистості психолога, проведений аналіз його професійно важливих якостей (О.Ф. Бондаренко, І.В. Дубровіна, Н.М. Макаренко, С.Д. Максименко, С.А. Медведєва, К.В. Пилипенко, Н.І. Пов'якель, Н.В. Пророк, Л.В. Скрипко, Н.В. Чепелєва та ін.); також досліджувалися психологічні умови формування готовності й професійного розвитку особистості психолога до різних аспектів професійної діяльності (Ж.П. Вірна, Л.В. Долинська, І.А. Дружиніна, Л.Е. Орбан-Лембрик, В.Д. Потапова, О.П. Саннікова, Т.М. Титаренко, Ю.Г. Шапошнікова й ін.).

Однак проблема комунікативної готовності майбутніх психологів до професійної діяльності як складник зазначеної психологічної готовності в умовах навчання у ЗВО не досліджена, а тому $є$ актуальною в сучасній психології й потребує наукового вивчення.

Постановка завдання. Мета статті - визначити теоретико-методологічні засади та психологічні умови розвитку комунікативної готовності майбутніх психологів до професійної діяльності.

Виклад основного матеріалу дослідження. Ми погоджуємося з думкою Є.О. Варлакової, яка вважає, що готовність варто розглядати на особистісному рівні, оскільки особистість психолога є фактично інструментом його професійної діяльності [3, с. 27]. Готовність майбутніх психологів $€$ істотною передумовою цілеспрямованої професійної діяльності, налаштування психолога на запобігання ситуаціям і конструктивне розв'язання будь-яких ситуацій на емоційному, комунікативному, мотиваційному, операційному та когнітивному рівнях.

У структурі зазначеної готовності ми зосередимося на комунікативному складнику, що забезпечує комунікативну толерантність психолога під час роботи з людьми (прийняття індивідуальності клієнтів, відсутність оцінних висловлювань на їхню адресу, терпимість до їхніх дискомфортних станів, згладжування неприємних моментів у спілкуванні з некомунікабельними клієнтами), а також здатність адекватно використовувати й розпізнавати сигнали невербального мовлення в спілкуванні з клієнтом [1, с. 69] (рис. 1).

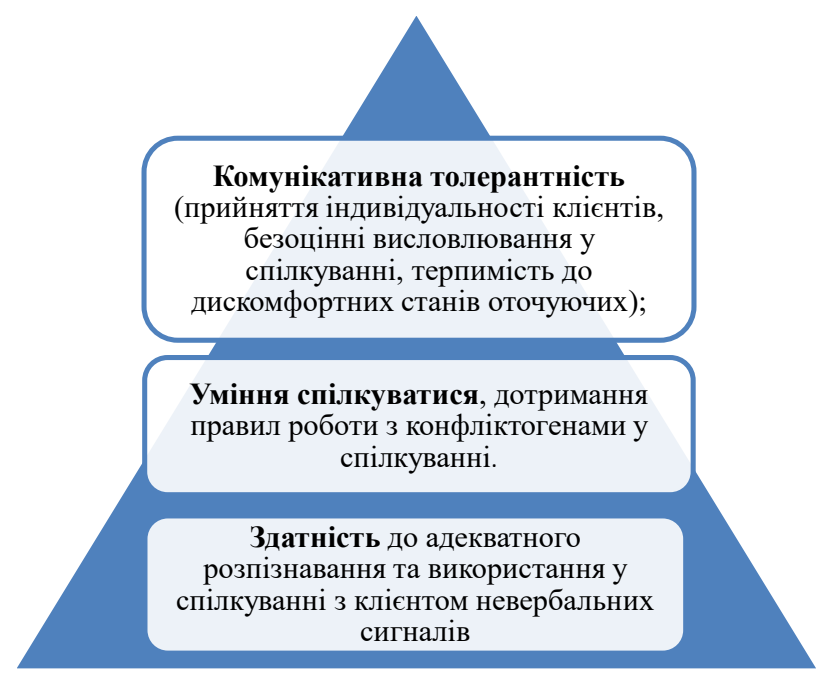

Рис. 1. Складники комунікативної готовності психолога до професійної діяльності

Для забезпечення ефективної взаємодії й адекватного взаєморозуміння між людьми в процесі спілкування майбутній психолог повинен володіти комунікативними здібностями, які дають змогу успішно вступати в контакт з іншими людьми та приймати рішення стосовно певних комунікативних завдань.

Важливими компонентами в структурі комунікативних здібностей С.М. Бучацька вважає «соціальну перцепцію (сприйняття, розуміння й оцінювання інших людей, самих себе, груп тощо); вольові якості; інтеракційні вміння у «подавати себе», уміння орієнтуватися на співрозмовника); сприйняття й адекватне розуміння різного роду знакових систем: вербальної та невербальної, пара- й екстралінгвістичної (інтонації, паузи), оптико-кінетичної (жести, міміка, пантоміміка) з метою обміну інформацією, сприйняття й розуміння іншої людини, вироблення стратегії взаємодії» [2, с. 37].

Комунікативна готовність як сукупність комунікативних властивостей і здібностей, що забезпечують конструктивне спілкування психолога під час професійної взаємодії з клієнтом, сприяє ефективній взаємодії й адекватному взаєморозумінню між людьми в процесі спілкування чи виконання спільної діяльності.

Однак майбутній психолог, який після закінчення ЗВО повинен надавати реальну професійну допомогу реальним клієнтам, запам'ятавши певну послідовність вправ і дійшовши висновку, що існує певна схема, певна послі- 
довність дій, автоматичне застосування яких може допомогти людині розв'язати її проблему, як правило, залишається безпорадним під час зустрічі з реальністю психологічної практики.

У результаті опитування студентів 4 курсу встановлено, що через дефіцит необхідної профорієнтаційної інформації як про зміст і психологічну структуру діяльності психологів, так і про психологічні вимоги, які висуваються до психологів, студенти не можуть здійснити адекватну професійну самоідентифікацію, щоб зрозуміти, чи відповідають їхні особистісні якості та психологічні дані вимогам обраної спеціалізації. Така самоідентифікація базується лише на інтуїтивній самооцінці. Існує також думка про відсутність толерантного соціально-психологічного середовища у $3 \mathrm{BO}$ та несприятливий соціально-психологічний клімат у студентських групах, який не сприяе конструктивній взаємодії між студентами.

Отже, ми мали на меті дослідити особливості розвитку комунікативної готовності майбутніх психологів до професійної взаємодії, визначити рівень розвитку всіх їі компонентів. У дослідженні взяли участь 54 студенти 4 курсу спеціальності «Психологія» Вінницького державного педагогічного університету імені М. Коцюбинського, з яких - 27 осіб включено в експериментальну групу і 27 осіб - у контрольну.

Емпіричними референтами комунікативної готовності стали комунікативна толерантність (інтолерантність), уміння спілкуватися та рівень розуміння майбутніми психологами сигналів невербального мовлення, для визначення рівня яких відібрані відповідні методики (таблиця 1).

Для визначення комунікативної інтолерантності ми використали методику В.В. Бойка [4], яка давала можливість перевірити таке: 1) якою мірою особистість здатна приймати (не приймати) індивідуальності тих людей, із якими має справу; 2) чи немає в неї тенденції оцінювати людей, виходячи з власного «я»; 3) якою мірою вона є категоричною та чи є незмінними її оцінки на адресу оточуючих; 4) якою мірою вона вміє приховати неприємні враження від спілкування з некомунікабельними людьми; 5) чи є в неї схильність перевиховувати інших людей; 6) якою мірою вона схильна підганяти людей під себе, робити їх зручними; 7) чи властива їй тенденція ображатися на інших, довго пам'ятати образи; 8) якою мірою вона терпима до дискомфортних станів інших людей; 9) які їі адаптаційні можливості у взаємодії з людьми тощо. Чим більше балів за кожною ознакою і за загальною сумою балів отримував досліджуваний, тим нижчим уважався рівень його комунікативної толерантності.

Діагностика вміння спілкуватися за методикою М. Снайдера [5] давала змогу визначити, наскільки гарним співрозмовником може стати майбутній психолог, чи вміє він уважно слухати іншого, не перебивати його, дати час на те, щоб висловити свою думку. Чим більшим був відсоток прикрих ситуацій, що викликали роздратування в досліджуваного, тим нижчим уважався рівень його вміння спілкуватися.

За допомогою методики визначення рівнів розуміння сигналів невербального мовлення (за М. Снайдером) [5] стало можливим з'ясувати рівень обізнаності майбутніх психологів щодо невербального мовлення та його сигналів, визначити ступінь їхньої спостережливості в процесі спілкування. Чим більше балів за загальною сумою балів отримував досліджуваний, тим вищим уважався рівень його розуміння сигналів невербального мовлення.

Критеріями оцінювання рівня сформованості комунікативної готовності майбутніх психологів до професійної взаємодії стали ступінь прийняття індивідуальності клієнтів, терпимості до їхніх дискомфортних станів, категоричності й незмінності їхніх оцінок на адресу оточуючих, прагнення перевиховати їх, а також ступінь усвідомлення й регулювання сигналів невербального мовлення тощо.

За результатами даних методик, відповідно до вищезазначених критеріїв, ми мали змогу розподілити досліджуваних на групи з високим, середнім або низьким рівнями комунікативної готовності. Високий рівень комунікативної готовності визначався в разі низького рівня комунікативної інтолерантності майбутніх психологів у поєднанні з високими рівнями розвитку вміння слухати та розуміння сигналів невербального мовлення.

За переважно середніх рівнів комунікативної інтолерантності, уміння слухати та розуміння

Методична база дослідження комунікативної готовності майбутніх психологів

Таблиця 1 до професійної діяльності

\begin{tabular}{|l|l|}
\hline \multicolumn{1}{|c|}{$\begin{array}{c}\text { Компоненти } \\
\text { комунікативної готовності }\end{array}$} & \multicolumn{1}{|c|}{ Методика } \\
\hline $\begin{array}{l}\text { Комунікативна толерантність } \\
\text { (інтолерантність) }\end{array}$ & Методика В.В. Бойка [4] \\
\hline Уміння спілкуватися & Методика діагностики вміння спілкуватися (за М. Снайдером) [5] \\
\hline $\begin{array}{l}\text { Рівень розуміння сигналів } \\
\text { невербального мовлення }\end{array}$ & $\begin{array}{l}\text { Методика визначення рівнів розуміння сигналів невербального } \\
\text { мовлення (за М. Снайдером) [5] }\end{array}$ \\
\hline
\end{tabular}


сигналів невербального мовлення ми констатували середній рівень комунікативної готовності, а низький рівень - у разі високого рівня комунікативної інтолерантності й недостатньо розвинутого вміння слухати співрозмовника, розуміти невербальні сигнали, які він посилає в процесі спілкування.

Діагностика компонентів комунікативної готовності дала змогу ознайомитися 3 деякими поведінковими ознаками майбутніх психологів, що свідчать про низький рівень $(3,4 \%)$ загальної комунікативної толерантності. Констатовано, що в досліджуваних існують певні проблеми з проявами терплячості до людей у тому чи іншому аспекті взаємин із ними, зокрема в здатності приймати індивідуальності людей та ображатися на інших. У переважної кількості майбутніх психологів $(93,4 \%)$ установлено середній рівень комунікативної толерантності, лише 3,2\% майбутніх психологів виявили високий рівень.

Варто визнати, що далеко не всі психологи добре обізнані із сигналами невербального мовлення, які могли б підказати, які емоції переживає клієнт у ситуації взаємодії з психологом, не знають, на що звертати увагу, щоб правильно декодувати їх. Лише 24,6\% досліджуваних мають високий рівень обізнаності щодо сигналів невербального мовлення, демонструючи високий рівень спостережливості. Значна частина майбутніх психологів $(68,7 \%)$ недостатньо обізнана зі змістом таких сигналів, а 6,6\% узагалі його не знають.

За результатами діагностики студенти розподілені на 3 групи: 3 високим $(32,0 \%)$, середнім $(52,0 \%)$ і низьким $(16,0 \%)$ рівнями комунікативної готовності до професійної діяльності (таблиця 2).

Таблиця 2

Рівні розвитку комунікативної готовності майбутніх психологів до професійної діяльності (1 зріз)

\begin{tabular}{|l|c|c|}
\hline \multirow{2}{*}{$\begin{array}{c}\text { Рівні } \\
\text { розвитку }\end{array}$} & \multicolumn{2}{|c|}{ Кількість досліджуваних (у \%) } \\
\cline { 2 - 3 } & $\mathbf{E Г}$ & КГ \\
\hline Низький & 16,0 & 18,5 \\
\hline Середній & 52,0 & 51,9 \\
\hline Високий & 32,0 & 29,6 \\
\hline
\end{tabular}

Результати дослідження засвідчили необхідність організації спеціального навчання (тренінгу) з метою розвитку комунікативної готовності майбутніх психологів до професійної взаємодії, а саме розвитку в студентів професійно важливих якостей особистості, гуманістичної спрямованості, зокрема «діалогічності» як центрального їі компонента, а також здатності до професійної ідентифікації [8, с. 17-19].

Під час створення програми розвитку комунікативної готовності ми ґрунтувалися на положеннях, що розвиток комунікативної сфери - це передусім саморозвиток особистості й удосконалення нею засобів організації комунікативної взаємодії в процесі соціально-психологічного тренінгу, унаслідок чого відбувалося усвідомлення студентами власних установок у комунікативній сфері, експлікація наявних і вироблення продуктивніших моделей пізнання особистості партнерів по спілкуванню, освоєння певного рівня особистісної рефлексії та розвиток рефлексивного ставлення до себе як до суб'єктів професійного спілкування, вироблення вміння диференціювати й адекватно виражати власні почуття, використовуючи при цьому весь арсенал вербальних і невербальних засобів комунікації $[7$, с. 79$]$.

Метою тренінгу насамперед передбачався розвиток здатності до зчитування невербальних сигналів на основі візуальної психодіагностики та виконання комплексу психогімнастичних вправ, що спрямовані на розслаблення, зняття експресивно-рухових затисків. Така невербальна активність сприяла розкутості емоційної сфери людини, допомагала набути майбутніми психологами навичок «зчитування» невербальних сигналів, здатності розуміти внутрішній стан людини за ії мімікою, жестами, пантомімікою. Так, для розвитку вміння розуміти невербальні ознаки спілкування, мову рухів тіла, емоційні стани, управляти голосом використана вправа «Жести примирення». За умовами вправи учасники мали визначити доречність використаних невербальних сигналів, відповідність їх ситуації. А під час виконання вправи «Хто ви?» кожному учаснику пропонувалося написати характеристики невербальної поведінки одного з інших учасників тренінгу. Коли характеристики зачи-

Основні напрями формування комунікативної готовності майбутніх психологів до професійної діяльності в процесі реалізації тренінгу

\begin{tabular}{|l|l|}
\hline \multicolumn{1}{|c|}{$\begin{array}{l}\text { Проблеми } \\
\text { (недостатній рівень розвитку) }\end{array}$} & \multicolumn{1}{|c|}{ Засоби корекції } \\
\hline$-\quad$ комунікативна інтолерантність, \\
- недостатні вміння «зчитування» \\
невербальної інформації, \\
$-\quad$ експресивність у спілкуванні. & $\begin{array}{l}\text { Застосування когнітивно-поведінкових методів, } \\
\text { самостійна робота (виконання домашніх завдань). } \\
\text { Вправи: авторська модифікація вправ: «Жести } \\
\text { примирення», «Техніка одного питання», «Критика», «Ні», } \\
\text { «Позитив і негатив» [6]. }\end{array}$ \\
\hline
\end{tabular}


тувалися, група мала визначити, кому належить ця характеристика.

Вправа «Позитив і негатив» допомагала виробити навички толерантного ставлення до різних точок зору учасників дискусії. Під час процесу було важливо не стільки детально обговорювати аргументи, скільки створити уявлення про те, що точок зору (як позитивних, так і негативних) може бути багато. Обговорення стосувалося досвіду, отриманого під час виконання вправи, аналізу аргументів, особливо тих, які давалися нелегко.

Вироблення навичок спілкування відбувалося шляхом репетиції конструктивної поведінки в різних ситуаціях, при цьому використовувалися вправи, які сприяли усвідомленню звичних способів спілкування, аналізу помилок у міжособистісній взаємодії. Наприклад, у вправі «Ні» група просила учасника зробити щось, що він не зобов'язаний робити. Завдання учасника - послідовно, протягом трьох хвилин відмовити групі в проханні, запобігаючи виникненню конфліктної ситуації.

Метою вправи «Критика» було вироблення вміння користуватися алгоритмом конструктивної критики. Учасники по черзі сідали на «гарячий стілець» і піддавалися критиці, на яку мали відповідати. Після цього відбувалося обговорення правильних форм реагування на критику, їх допустимі форми та межі.

3 метою вивчення ефективності тренінгу у формуванні комунікативної готовності майбутніх психологів до професійної діяльності проведено повторну діагностику. Аналіз результатів упровадження тренінгу в процес навчання майбутніх психологів у ЗВО вказує на його ефективність. Порівняльний аналіз результатів першого та другого зрізів, проведених в експериментальній і контрольній групах, показав, що в експериментальній групі спостерігається позитивна динаміка рівнів розвитку комунікативної готовності, тоді як у контрольній групи статистично значущих відмінностей у рівнях розвитку такої готовності не зафіксовано.

Зокрема, як свідчить порівняльний аналіз результатів до формувального експерименту (1 зріз), між експериментальною й контрольною групами відсутні істотні відмінності в рівнях готовності студентів. Результати після формувального експерименту (2 зріз) в експериментальній групі свідчать про наявність позитивної динаміки готовності майбутніх психологів до професійної взаємодії, тоді як у контрольній групі такої динаміки практично не зафіксовано (рис. 2, 3).

Аналіз результатів підсумкового тестування свідчить про те, що в експериментальній групі в результаті тренінгу зафіксовано значні зміни, які відображають зменшення кількості студентів із низьким рівнем готовності (з 16,0\% до 4,0\%), збільшення кількості студентів із високим рівнем готовності (з 32,0\% до 56,0\%). Натомість у контрольній групі ми констатували незначне зменшення кількості досліджуваних із низьким рівнем розвитку комунікативної готовності (з 18,5\% до 14,8\%) і збільшення кількості досліджуваних із середнім рівнем її розвитку з 51,9\% до 55,6\%, яке не є значущим.

Помітною була позитивна тенденція й до розвитку емпатії студентів експериментальної групи, які проявляли справжній інтерес, розуміння значущості й цінності особистості іншого, не допускали відчуженості й байдужості щодо переживань іншого, були більш

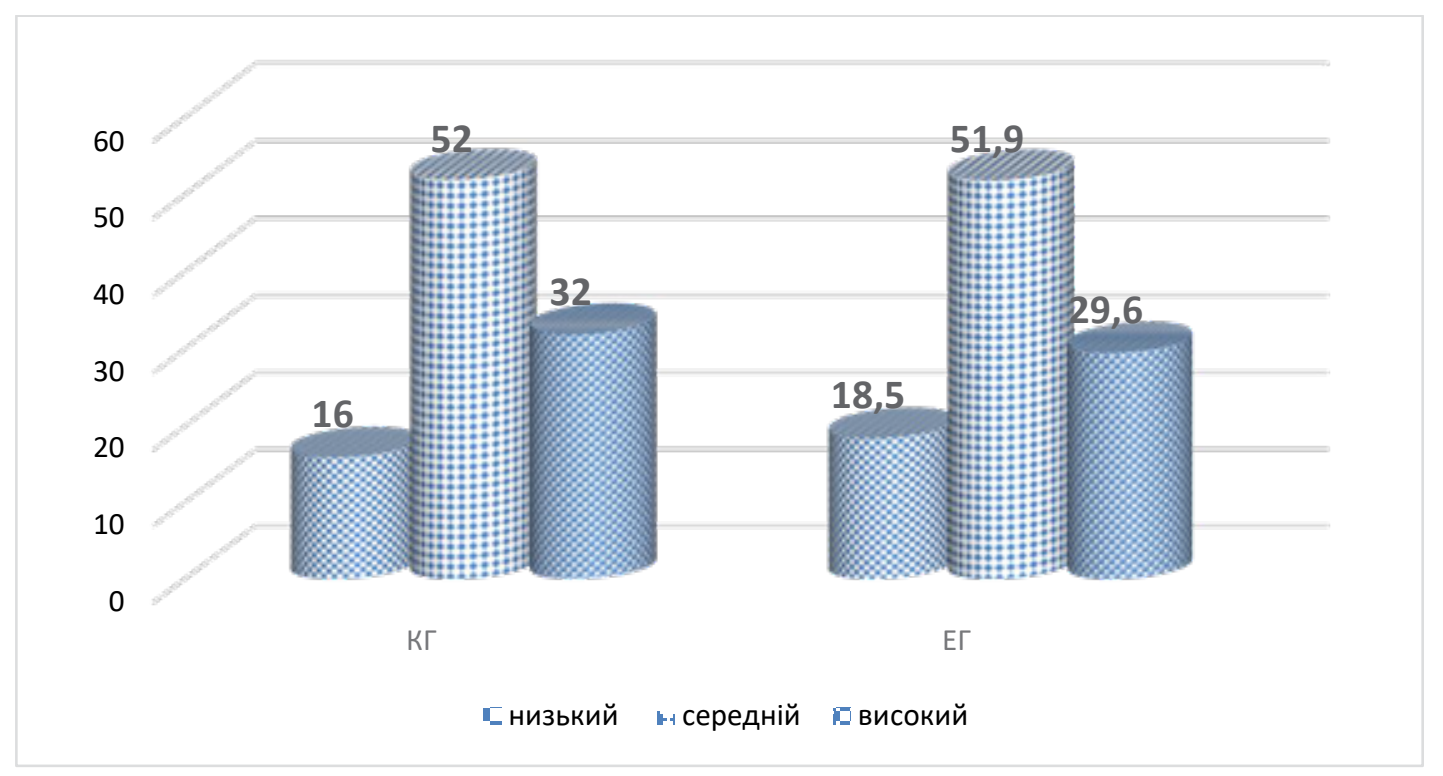

Рис. 2. Рівні розвитку комунікативної готовності майбутніх психологів до професійної взаємодії (1 зріз)

1 - низький рівень, 2 - середній рівень, 3 - високий рівень 


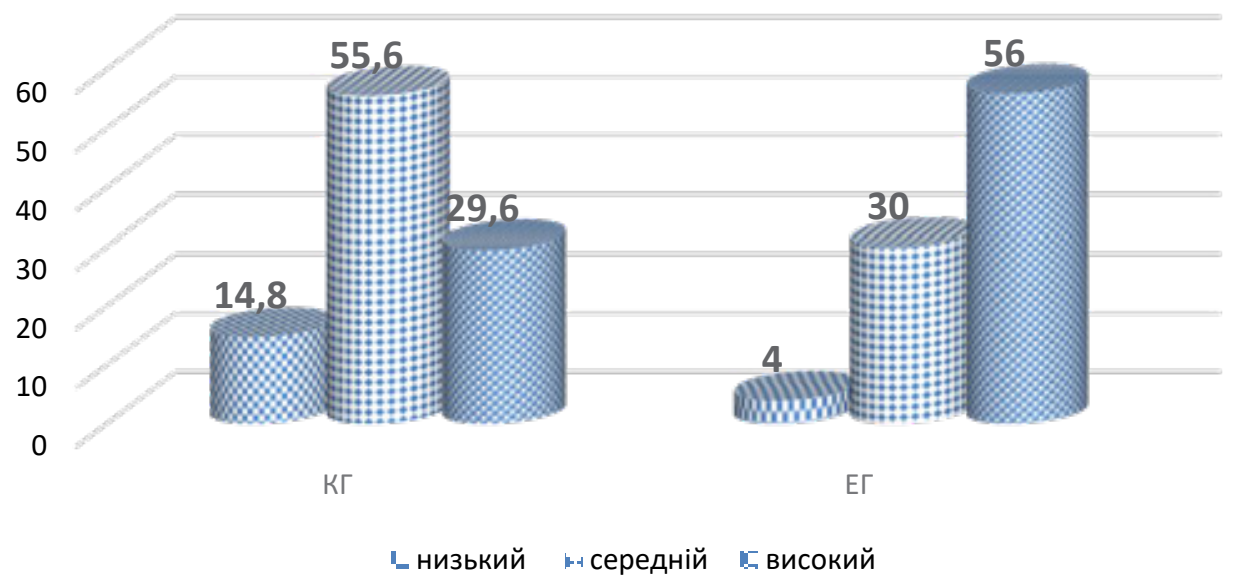

Рис. 3. Рівні розвитку комунікативної готовності майбутніх психологів до професійної взаємодії (2 зріз)

1 - низький рівень, 2 - середній рівень, 3 - високий рівень

Таблиця 4

Рівні розвитку комунікативної готовності майбутніх психологів до запобігання конфліктам і розв'язання конфліктів (2 зріз)

\begin{tabular}{|l|c|c|}
\hline \multirow{2}{*}{$\begin{array}{c}\text { Рівні } \\
\text { розвитку }\end{array}$} & \multicolumn{2}{|c|}{ Кількість досліджуваних (у \%) } \\
\cline { 2 - 3 } & $\mathbf{E Г}$ & КГ \\
\hline Низький & 4,0 & 14,8 \\
\hline Середній & 30,0 & 55,6 \\
\hline Високий & 56,0 & 29,6 \\
\hline
\end{tabular}

терпимі до недоліків інших, ніж студенти контрольної групи.

Отримані результати свідчать про досить високу ефективність розробленої нами програми, утіленої в тренінгу, щодо вироблення вмінь конструктивно спілкуватися в напружених ситуаціях взаємодії з клієнтом.

Висновки з проведеного дослідження. Отже, можна констатувати, що під час апробації програми формувального експерименту зріс рівень готовності майбутніх психологів з експериментальної групи до запобігання конфліктам і розв'язання конфліктів. У результаті студенти експериментальної групи відрізнялися більшою вмотивованістю до професійної діяльності й набуття відповідних знань, умінь, навичок, умінням обирати оптимальний стиль поведінки в напружених ситуаціях взаємодії, більшою здатністю до саморегуляції негативних емоційних станів і більш вираженою емпатією до клієнтів у процесі професійної взаємодії.

\section{ЛІТЕРАТУРА:}

1. Антонова Н.О. Концептуальні основи тренінгу готовності до професійної діяльності психолога. Актуальні проблеми психології : збірник наукових праць Інституту психології ім. Г.С. Костюка АПН України ; за ред. С.Д. Максименка. Київ, 2010. Т. XII. Ч. 4. C. 14-26.

2. Бучацька С.М. Формування психологічної готовності студентів до ділового спілкування іноземними мовами : дис. ... канд. псих. наук : 19.00.07 / Національна академія Державної прикордонної служби України імені Богдана Хмельницького. Хмельницький, 2009. 219 с.

3. Варлакова Є.О. Формування готовності майбутніх практичних психологів до розв'язання міжособистісних конфрліктів : авторефр. дис. ... канд. психол. наук : 19.00.05 / Національна академія педагогічних наук України, Інститут психології ім. Г.С. Костюка. Київ : АПН України. ІП ім. Г. Костюка, 2011. 18 с.

4. Райгородский Д.Я. Практическая психодиагностика. Методики и тесты : учебное пособие. Самара : БАХРАХ-M, 2001. $672 \mathrm{c}$.

5. Реан А.А. Психология и психодиагностика личности. Теория, методы исследования, практикум. Санкт-Петербург : Прайм-ЕВРОЗНАК, 2006. 255 с.

6. Семенова Е.М. Тренинг эмоциональной устойчивости педагога : учебное пособие. 3-е изд. Москва : Психотерапия, 2006. 256 с.

7. Ставицька О.Г. Психологічні особливості використання невербальних засобів спілкування у діяльності вчителя : дис. ... канд. психол. наук : 19.00.07 / Державний вищий навчальний заклад «Університет менеджменту освіти». Київ, 2009. 264 с.

8. Чепелєва Н.В. Особистісна підготовка психолога-практика. Персонал. 2000. № 5. С. 17-19. 